\title{
KEPEMILIKAN RUMAH DAN BANGUNAN SEBAGAI JAMINAN PEMINJAMAN UANG PADA BANK
}

\author{
Mariani St.B Tanjung \\ Akademi Keuangan dan Perbankan Padang \\ mstbtanjung@gmail.com
}

\begin{abstract}
ABSTRAK
Economic life, the bank holds a very important role as a financial institution to assist the government in order to achieve a just and prosperous society as aspired. In carrying out its role, the bank is engaged in providing credit facilities/borrow money and at the same time serve to guide the organization's efforts. Banks provide loan facilities to entrepreneurs, especially small and economically weak, and traders who lack the capital to improve and expand its business with the terms of the mild and relatively easy procedure.
\end{abstract}

Keyword: guarantee, bank, home ownership

\section{LATAR BELAKANG}

Pembangunan sebagai suatu proses yang dilakukan secara sadar, di mana manusia sebagai anggota dari suatu masyarakat berusaha untuk mengolah kondisi yang menjadi landasan kehidupannya untuk mencapai tingkat kehidupan yang lebih baik.

Di negara yang sedang berkembang khususnya di Indonesia pemerintah akan selalu berusaha untuk meningkatkan kegiatan pembangunan dalam segala bidang guna mencapai kemakmuran rakyatnya. Pembangunan ini meliputi pembangunan secara fisik dan pembangunan non fisik. Pembangunan phisik adalah pembangunan dalam wujud konkrit termasuk disini adalah: pembangunan perubahan, pusat-pusat pertokoan, gedung-gedung perkantoran, jalan-jalan irigasi dan sebagainya. Sedangkan pembangunan non phisik adalah pembangunan dalam bentuk tak berwujud, seperti pembangunan pendidikan rohani, olahraga, seni dan budaya. Pembangunan disini adalah pembangunan phisik yang mendapat fasilitas pinjaman uang atau kredit dari bank.

Pemberian kredit merupakan salah satu usaha pemerintah dalam membantu meningkatkan pembangunan phisik, yaitu dengan memberikan bantuan-bantuan kredit kepada para pengusaha atau pemborong melalui bankbank pelaksana. Para pengusaha memberikan jaminan dalam bentuk rumah maupun bangunan lainnya demi lancarnya pemberian kredit. Dengan adanya dana yang diperoleh dari kredit tersebut dengan jaminan yang di berikan, pengusaha atau pemborong akan lebih giat melaksanakan pembangunan guna menuju masyarakat adil dan makmur yang dicita-citakan berdasarkan Pancasila dan Undang-undang Dasar 1945. 
Sehubungan negara kita adalah negara yang berdasarkan atas hukum, maka sebagai arah dan kebijaksanaan umum adalah pembangunan dibidang hukum Berdasarkan atas hal-hal tersebut dapat diambil kesimpulan, bahwa segala kegiatan atau perbuatan harus berdasarkan atas hukum. Demikian pula dengan masalah peminjaman uang perkreditan.

Kredit adalah suatu pemberian prestasi oleh suatu pihak lain dan prestasi itu akan dikembalikan pada suatu masa tertentu dengan disertai suatu kontra prestasi berupa bunga. Pinjam meminjam uang pada bank berkembang dikota-kota besar, karena pembangunan-pembangunan cukup banyak. Untuk pembangunan itu pengusaha sangat membutuhkan dana yang diperoleh melalui kredit bank. Untuk mendapatkan pinjaman dari bank maka pengusaha harus menyediakan jaminan baik tanah, rumah maupun bangunan bentuk lainnya. Dalam pemberian pinjaman ini pihak bank diharapkan sekali peranannya, dengan tata cara peminjamannya tidak menyimpang dari undangundang pokok perbankan maupun ketentuan bank Indonesia. Tingginya suku bunga pinjaman dan kurangnya pengetahuan pemohon dalam masalah pinjam meminjam uang serta rumah, bangunan atau surat-surat yang dijadikan jaminan bukan milik sendiri sehingga pihak bank enggan memberikan pinjaman sedangkan pengusaha nasabah butuh suntikan dana. Kurang telitinya pihak bank pada waktu memberikan kredit, dimana barang jaminan yang sudah pernah dijaminkan kepada bank lain dananya sudah melebihi dari jaminan kredit. Perlu pengurangan tingkat suku bunga, sehingga tidak terjadi kemacetan kredit.

\section{Perjanjian pada Umumnya \\ Pengertian Perjanjian}

Di dalam bahasa Indonesia perjanjian tersebut dengan "Overenkomst", ini diterjemahkan ke dalam bahasa Indonesia berarti perjanjian atau persetujuan. Perbedaan pandangan para sarjana untuk mengartikan istilah Overenskomt ini disebabkan sudut pandangan mereka berbeda-beda. Ada yang meninjau dari segi kehendak itu disetujui dengan ada yang memiliki dan apa yang melihat dari akibat yang ditimbulkan dari suatu perjanjian.

Menurut R. Subekti SH, perjanjian adalah suatu peristiwa dimana seorang berjanji kepada orang lain atau dimana dua orang saling berjanji kepada orang lain atau dimana seseorang berjanji kepada orang lain atau dimana dua orang saling berjanjian kepada orang lain untuk melaksanakan sesuatu hal.

Pasal 1313 kitab undang-undang hukum perdataan, menyebutkan bahwa:"Suatu persetujuan adalah perbuatan dengan mana satu orang atau lebih mengikatkan dirinya terhadap satu orang atau lebih.

Kalau dilihat perumusan pengertian perjanjian yang terdapat dalam pasal 1313 kitab undang-undang hukum perdata ini masih terlalu luas sifatnya dan belum menunjukkan ke dalam bentuk yang lebih konkrit ke dalam perjanjian itu. Oleh karena itu yang dimaksud dengan perjanjian adalah : suatu perbuatan hukum antara dua orang atau lebih yang saling berjanji untuk melaksanakan sesuatu hal dan di lain pihak menyanggupi prestasi. 
Perbuatan hukum disini ditekankan bahwa suatu perjanjian yang dilakukan oleh dua orang atau lebih di atur oleh hukum. Perbuatan yang telah dilakukan itu tidak dilaksanakan oleh salah satu pihak, sehingga menimbulkan kerugian bagi pihak lainnya. Dalam arti pihak itu wanprestasi atau tidak melakukan kewajibannya sebagai pihak yang berprestasi.

Dari perumusan pengertian perjanjian tersebut diperoleh dua unsur penting dalam suatu perjanjian, yaitu :

1. Suatu perbuatan hukum yang dilakukan oleh dua atau lebih

2. Perbuatan mana yang ditujukan untuk melaksanakan unsur itu harus dalam perjanjian meskipun bentuk dan jenis perjanjian itu beraneka ragam bentuknya.

Perjanjian dapat melahirkan suatu perikatan adalah perjanjian dapat melahirkan suatu perikatan atau perutangan, sebab perutangan atau perikatan bersumber dari perjanjian dan undang-undang.

Dengan demikian hubungan antara perjanjian dengan perikatan adalah perjanjian dapat melahirkan suatu peratan atau perutangan dan perjanjian merupakan salah satu sumber perikatan. Perikatan terjemahan dari istilah "Verbintesis" dan diatur dalam pasal 1233 kitab undang-undang hukum perdata yang berbunyi : "Tiap-tiap perikatan dilahirkan baik karena perjanjian, baik karena Undang-Undang”. Selanjutnya pasal 1234 kitab Undang-Undang hukum perdata menyebutkan: "Tiap-tiap perikatan adalah untuk memberikan sesuatu, atau untuk tidak berbuat sesuatu".

Sifat perikatan atau perutangan itu adalah abstrak, Sedangkan perjanjian sifatnya adalah konkrit. Di sini penulis akan membicarakan kedua sifat tersebut secara terperinci. Demikian juga halnya perikatan atau perutangan baik yang terjadi menurut Undang-undang maupun yang bersumber kepada suatu perjanjian.

\section{Syarat-syarat sahnya Perjanjian}

Dalam melakukan suatu perjanjian agar perjanjian dapat dilaksanakan harus memenuhi kriteria tertentu. Kriteria tersebut adalah mengenai syarat-syarat perjanjian, agar perjanjian itu sah dan mengikat.

Dalam pasal 1320 kitab Undang-Undang hukum perdata menyebutkan ada empat syarat yang harus dipenuhi dalam suatu perjanjian yang berbunyi : "Untuk sahnya suatu perjanjian diperlukan empat syarat :

1. Sepakat mereka yang mengikatkan diri

2. Kecakapan untuk membuat suatu perjanjian

3. Suatu hal tertentu

4. Suatu sebab yang halal

Syarat-syarat perjanjian menurut pasal 1320 kitab Undang-Undang hukum perdata tersebut dapat dikelompokkan menjadi :

1. Syarat Subyektif.

Syarat subyektif dalam suatu perikatan atau perjanjian berkaitan erat dengan para pihak yang melakukan suatu perjanjian yaitu:

a. Sepakat mereka mengikatkan dirinya.

b. Kecakapan untuk membuat suatu perjanjian 
2. Syarat Objektif.

Syarat objektif dalam suatu perjanjian berkaitan erat dengan objek dari perjanjian itu sendiri yang meliputi:

a. Suatu hal tertentu

b. Suatu sebab yang halal

Apabila suatu perjanjian tidak dipenuhinya persyaratanpersyaratan seperti tersebut diatas maka perjanjian yang telah disepakati itu dapat diancam kebatalan atau pembatalan.

Perjanjian yang dapat diancam kebatalam atau dimintakan pembatalannya apabila perjanjian tersebut tidak memenuhi syarat subyektif. Undang-Undang menyebutkan bahwa "setiap orang adalah cakap untuk berbuat perikatan, Jika ia oleh Undang-Undang tidak dinyatakan tidak cakap (pasal 1329kitab Undang-undang hukum perdata)".

Di dalam pasal 1330 kitab Undang-Undang hukumperdata menyebutkan bahwa:'Tak cakap untuk membuat perjanjian adalah :

1. Orang-orang yang belum dewasa.

2. Mereka ditaruh dibawah pengampuan.

3. Orang-orang pengampuan dalam hal yang ditetapkan oleh undangundang telah melarang membuat perjanjian-perjanjian tertentu. (hal ini sudah dicabut dengan keluarnya surat edaran mahkamah agung No. 3 tahun 1963).

Perjanjian yang dilakukan secara tidak sah yang juga karena kekhilafan, penipuan dan pemaksaan juga dibatalkan. Seperti yang di atur dalam pasal 11322, 1323 dan pasal 1328 Undang-Undang hukum perdata.

Untuk pembatalan perjanjian yang tidak memenuhi persyaratan subyektif ini harus dimohonkan kepada hakim dan pembatalan ini harus diajukan oleh pihak yang lemah atau pihak yang dirugikan. Pihak yang diragukan dapat memilih tiga hal mengajukan kepada hakim, yaitu :

1. Ganti rugi

2. Pembatalan perjanjian disertai ganti rugi

3. Peralihan resiko

Dalam hal ini hakim mempunyai kewenangan discrisionare apabila ada tuntutan pihak yang dirugikan, artinya hakim berwenang menilai besar kecilnya wanprestasi yang dilakukan. Akibatnya hakim dapat memberikan keputusan yang seadil-adilnya.

Namun demikian pihak yang lemah atau pihak yang dirugikan menguatkan perjanjian yang telah mereka buat, maka syahlah perjanjian. Sifat perjanjian yang demikian ini pada prinsipnya adalah sah sepanjang tidak dimohonkan pembatalan. Akan tetapi perjanjian demikian tidak sempurna diancam kebatalannya atau ada kepastian.

Perjanjian yang tidak memenuhi syarat obyektif, maka perjanjian tersebut batal demi hukum dapat diklasifikasikan menjadi dua, yaitu : 
1. Batal Absolut.

Suatu perjanjian batal secara absolut, apabila perjanjian itu tidak memenuhi bentuk-bentuk tertentu yang ditentukan, maka perjanjian-perjanjian tersebut batal demi hukum.

2. Batal Relatif

Perjanjian yang batal secara relatif hanya berlaku bagi pihak-pihak yang membuatnya dan tidak berlaku bagi pihak ketiga yang dirugikan.

Misalnya: perjanjian jual beli tanah yang dibuat suami istri, dan lain sebagainya.

Dalam salah satu azas dalam hukum perjanjian yaitu azas kebebasan berkontrak adapun unsur-unsur untuk membuat perjanjian adalah :

a. Bebas untuk mengadakan atau tidak mengadakan perjanjian.

b. Bebas untuk menentukan sendiri mengenai isi ataupun syarat-syarat perjanjian.

c. Bebas untuk mengadakan perjanjian dengan siapapun, meskipun demikian asas kebebasan berkontrak ini ada pembatasan berlakunya, baik pembatasan yang ditentukan oleh undang-undang ataupun sebagai akibat perkembangan dalam masyarakat.Pembatasan kebebasan berkontrak antara lain meliputi:

a. Asas tidak bertentangan dengan undang-undang, ketertiban umum dan kesusilaan.

b. Dengan pertumbuhan masyarakat khususnya di bidang ekonomiterjadi penggabungan-penggabungan atau pemusatanpemusatan tadi.

c. Adanya aliran dalam masyarakat yang menuju kearah penegakan keadilan sosial, sehingga adanya usaha-usaha baik di dunia barat maupun di Indonesia untuk memberantas perjanjian yang tidak memenuhi rasa keadilan.

d. Dengan adanya campur tangan pengusaha dalam rangka melindungi kepentingan umum dan golongan yang lemah telah melahirkan Undang-Undang yang telah menguntungkan umum atau golongan lemah, sehingga kebebasan orang perseorangan makin terbatas saja. Pembatasan lebih kongkrit misalnya adanya bentuk perjanjian standar misalnya adanya bentuk perjanjian standar A V 1941 dalam perjanjian pemborongan bangunan yang melibatkan adanya campur tangan pihak pengusaha

\section{Jenis-Jenis Perjanjian}

Menurut Burma Burhan dalam diktat kuliah Fakultas Hukum Unand, jenisjenis perjanjian atau macam atau macam perjanjian adalah sebagai berikut

1. Perjanjian sepihak

Suatu perjanjian yang senantiasa hanya membebani kewajiban-kewajiban salah satu pihak saja. Sedangkan pihak yang lain tidak dibebani kewajiban melakukan hanya memperoleh hak dari pihak lain. 
Misalnya: Pinjam meminjam (Pasal 1754 kitab Undang-Undang hukum perdata).

2. Perjanjian Timbal Balik

Suatu perjanjian yang dilakukan secara timbal balik di mana para pihak saling mempunyai hak dan kewajiban yang timbal balik pula.

3. Perjanjian Konsensual

Adalah bentuk perjanjian dimana perjanjian tersebut telah lahir dengan adanya kata sepakat dari para pihak. Jadi adanya perjanjian harus berdasarkan persetujuan kehendak belaka. Hal ini dapat dilihat dalam pasal 1338 kitab Undang-Undang hukum perdata.

4. Perjanjian Rill

Perjanjian Rill merupakan suatu bentuk perjanjian dimana perjanjian itu baru lahir dengan adanya prestasi yang nyata-nyata telah dilakukan.

Misalnya : Perjanjian penitipan barang serta pinjam pakai.

5. Perjanjian Bernama

Perjanjian bernama merupakan suatu bentuk perjanjian seperti yang terdapat di dalam bentuk perjanjian seperti yang terdapat di dalam kitab undang-undang hukum perdata bku III bab V-XVIII, dan kitab UndangUndang hukum dagang seperti Angkutan, Fiema, CV, PT.

6. Perjanjian Tak Bernama

Perjanjian tak bernama adalah perjanjian yang tidak tertentu, yang biasanya terbatas atau perjanjian yang tidak terdapat dalam kitab UndangUndang hukum perdata tetapi terdapat dalam masyarakat.

7. Perjanjian Tertulis

Suatu perjanjian yang yang harus dibuat berdasarkan kesepakatan tertentu, seperti perjanjian perdamaian harus dibuat dalam bentuk tulis.

\section{Hapusnya Perjanjian}

Perjanjian atau suatu persetujuan dapat hapus, karena :

1. Ditentukan dalam persetujuan oleh para pihak.

Misalnya : Persetujuan akan berlaku untuk waktu tertentu.

2. Undang-Undang menentukan batas berlakunya suatu persetujuan.

Misalnya : menurut pasal 1066 ayat 3 bahwa para ahli waris dapat mengadakan persetujuan untk selama waktu tertentu untuk tidak melakukan pemecahan harta warisan. Akan tetapi waktu persetujuan tersebut oleh pasal 1066 ayat 4 dibatasi berlakunya hanya untuk lima tahun.

3. Para pihak Undang-Undang dapat menentukan bahwa dengan terjadinya peristiwa tertentu maka persetujuan akan menjadi hapus.

- Persetujuan perseorangan pasal 1646 ayat 4

- Persetujuan pemberian kuasa pasal 1813.

- Persetujuan kerja pasal 1613

4. Pernyataan menghendaki persetujuan (Opzeging).

Opzeging dapat dilakukan oleh kedua atau oleh salah satu pihak. Opzeging hanya ada persetujuan yang bersifat sementara,

Misalnya : - Persetujuan kerja

- Persetujuan menyewa 
5. Persetujuan hapus karena keputusan hakim

6. Tujuan persetujuan telah tercapai

7. Dengan persetujuan telah tercapai (herroeping) ( R.Setiawan SH 1970)

Menurut pasal 1381 kitab Undang-Undang hukum perdata ada 10 cara hapusnya verbintesis (perikatan) :

1. Pembayaran

Suatu perjanjian yang dilakukan dapat hapus karena dilakukannya pembayaran. Ketentuan ini dapat dilihat dalam pasal 1382-1403 kitab undang-Undang hukum perdata. Hapusnya perjanjian karena pembayaran ini perlu diperhatikan adalah :

a. Siapa yang harus membayar (pasal 1382 kitab Undang-Undang hukum perdata).

Pihak yang wajib membayar suatu hutang, bukan saja siberhutang (debitur), akan tetapi juga seorang lawan siberhutang dan seorang penanggung untuk bergtog. Jadi yang dapat membayar suatu hutang itu adalah debitur (siberhutang),

Penanggung dan pihak ketiga. Apabila hutang itu dibayar oleh pihak ketiga maka akan terjadi subrogasi (pasal 1400-1103 KUH perdata), meskipun adanya subrogasi akan tetapi kewajiban debitur tidak begitu saja hapus, kecuali telah ditentukan lain sebelumnya.

b. Kepada siapa pembayaran itu dilakukan (pasal 1383-1388 KUH perdata).

Pada prinsipnya pembayaran itu dilakukan kepada kreditur itu sendiri, ditetapkan oleh hakim atau undang undang oleh orang cakap menerimanya dan tidak syah apabila orang menerimanya tidak cakap.

c. Apa yang harus dibayar (pasal 1489-1392 KUH perdata).

Yang harus dibayar itu tergantung pada sifat dan isi perjanjian itu. Pada umumnya pembayaran itu dilakukan dengan uang, emas, surat berharga, cek dan lain sebagainya.

d. Tempat dan waktu pembayaran (pasal 1393, 1514, 1770 dan 17761 KUH perdata), tentang tempat dan waktu pembayaran dilihat dari perjanjian yang telah ditetapkan oleh para pihak dan bila ditetapkan dapat dipergunakan ketentuan-ketentuan yang terdapat dalam kitab Undang-Undang hukum perdata seperti yang dibuktikan dalam pasal di atas.

2. Penawaran dan pembayaran tunai, di ikuti dengan penyimpanan dan penitipan.

Hapusnya perjanjian dengan cara ini dimungkinkan dalam perjanjian membayar sejumlah uang atau menyerahkan barang-barang bergerak. Pasal 1402-1412 KUH perdata menegaskan bahwa hapusnya perjanjian karena adanya penawaran baik ditolak atau tidak ditolak oleh kreditur yang telah di ajukan debitur dapat menitipkan kepada pihak yang berwenang. Akibatnya debitur dapat dibebaskan untuk melakukan prestasi (pembayaran) bila ada tuntutan dari kreditur dengan mengemukakan adanya penawaran dan penitipan. 
3. Pembaharuan hutang (novasi).

Pembaharuan hutang atau inovasi ialah suatu persetujuan yang menyebabkan hapusnya perikatan dan pada saat yang bersamaan timbul perikatan lainnya yang ditetapkan sebagai pengganti perikatan semula. Pambaharuan hutang (Novasi) ialah :suatu perjanjian yang dengan itu suatu perjanjian yang sudah ada ditiadakan dan sekaligus dijadikan sebuah perjanjian yang baru. Jadi perjanjian yang hapus dengan diperbaharuinya perjanjian tersebut dan melahirkan sesuatu bentuk perjanjian yang baru, hutang yang lampau ikut hapus. Pambaharuan hutang atau novasi diatur dalam pasal 1413 sampai dengan pasal 1424 KUH Perdata.

4. Pencampuran Hutang atau Kompensasi.

Kompensasi dapat manghapuskan perjanjian yang telah dibuat. Kompensasi adalah suatu cars hapusnya perikatan yang disebabkan ole-h keadaan di mana dua orang masing-masing merupakan debitur satu dengan yang lainnya.

Misalnya A berutang kepada B sebesar Rp 2000,00 dan B juga ada hutang kepada A sebesar Rp 1.800,00.

Kedua hutang tersebut dikompensasikan tinggal sisa yang harus dibayar Rp 200,00.

Apabila hutang masing-masing debitur sama, maka habislah kedua hutangnya, akan tetapi apabila setelah dikompensasikan masih ada sisanya tidak malepaskan tanggung jawab untuk membayar yang tersisa itu. Kompensasi diatur dalam pasal 1425-1435 KUH Perdata.

5. Pencampuran Hutang.

Pencampuran hutang dapat menghapuskan perjanjian. Ini dapat terjadi apabila kedudukan debitur dan kreditur bersatu menjadi satu orang.

Misalnya kreditur meninggal dunia dan menunjuk debitur menjadi ahli warisnya karena tidak ada ahli waris yang lain. Pencampuran hutang di-atur dalam pasal 1436 jo 1437 Kitab Undang-Undang Hukum Pardata.

6. Pembebasan Hutang.

Pembebasan hutang adalah parbuatan hukum dl mana dengan itu kreditur melepaskan haknya untuk menagih piutangnya dari kreditur Dengan demikian debitur dapat bebas untuk tidak melakukan pembayaran hutangnya kepada kreditur dan an dapat. Menghapus perjanjian telah dilakukan. Pembebasan hutang telah diatur dalam pasal 1438 s/d 1443 Kitab Undang-Undang hukum Perdata.

7. Musnahnya Barang Terhutang.

Dengan musnahnya atau hilangnya barang yang terutang dapat membebaskan debitur untuk membayar hutangnya kepada kreditur dan dapat menghapuskan perjanjian yang telah disepakati atau di perjanjikan asal barang yang musnah atau hilang itu di luar kehendak debitur (si berhutang) sebelum ia lalai. untuk menyerahkannya.

Musnahnya barang yang terutang dalam pasal1444 dan pasal 1445 KUH Perdata. 
8. Kebatalan dan Pembatalan.

Dalam membicarakan kebatalan dan pembatalan yang dapat menghapuskan perjanjian, telah diuraikan dalam membicarakan syaratsyarat perjanjian (pasal 1320 Kita") Undang-Undang Hukum Perdata) Kebatalan dan pembatalan lebih. lanjut diatur dalam pasal 1446-1456 KUH Pardata.

Pasal 1446 Kitab Undang-Undang Hukum Perdata menerangkan "Semua perikatan yang dibuat oleh orang-orang belum dewasa atau orang-orang yang ditaruh di bawah pengampunan adalah batal demi hukum, dan atas penuntutan yang dimajukan oleh atau dari pihak mereka harus dinyatakan batal semata-mata atas dasar kebelum dewasaan atau pengampunannya. Pasal "1456 KUHP menerangkan :

'Tuntutan untuk pernyataan batal gugur, jika orang belum dewasa, orang yang ditaruh di bawah pengampunan, perempuan yang bersuami yang bertindak tanpa bantuan suaminya, atau orang yang dapat memajukan adanya paksaan, kekilafan. atau, penipuan, secara tegas atau secara diam-diam telah menguatkan perikatannya setelah ia menjadi dewasa.

9. Berlakunya Suatu.Byarat Batal.

Perjanjian menjadi hapus karena berlakunya suatu ketentuan syarat batal. Dalam perikatan bersyarat ditegaskan bahwa "Suatu isyarat batal adalah syarat yang apabila dipenuhi, menghentikan perikatan dan membawa sesuatu kembali pada keadaan semula seolah-olah pernah ada suatu perikatan. (pasal 1265 Jo pasal 1266 KUH Perdata). Dengan demikian syarat batal mewajibkan si berhutang untuk mengembalikan apa yang telah diterimanya, apabila peristiwa yang dimaksud terjadi.

10. Lewat Waktu (Daluarsa)

Parikatan menjadi hapus karena lewat waktu atau daluarsa. Bahwa dengan lewat waktu maka seseorang atau debitur manghapuskan pariloyan dan akan melepaskan kewajiban serta mendapatkan haknya kembali.

Hapusnya perikatan karena lewat waktu tidak diatur dalam Buku III akan tetapi diatur dalam Buku IV Kitab Undang-Undang Hukum Pardata pasal 1946 manyatakan bahwa " Daluarsa adalah suatu alat untuk memperoleh sesuatu atau untuk dibebaskan dari suatu perikatan dengan lewatnya suatu waktu tertentu dan atas syarat-syarat. yang ditentukan oleh undang-undang.

Kemudian pasal 1967 KUH Perdata menetapkan "Segala tuntutan hukum, baik yang bersifat perbedaan maupun yang bersifat perseorangan, hapus karena dalularsa dengan lewatnya waktu 30 tahun sedangkan siapa. yang menunjukkan akan adanya daluarsa itu tidak usah mempertunjukkan suatu atas hak, lagi Pula tak dapatlah dimajukan terhadapnya sesuatu tangkisan yang didasarkan kepada itikadnya yang buruk.

\section{Pengertian Lembaga Jaminan}

Memberikan suatu barang dalam Jaminan berarti melepaskan. sebagian. kekuasaan atas barang itu. 
Sebagaimana diketahui bahwa dalam praktek pinjam uang sering terjadi seorang peminjam tidak mau secara sukarela memenuhi kewajibannya untuk membayar kembali hutangnya tepat pada waktunya, ada juga peminjam tidak mau mengembalikan uang yang dipinjamkannya itu sama sekali.

Dengan adanya kejadian-kejadian seperti ini makes untuk menjamin bahwa pada waktunya orang yang meminjamkan uang itu benar-benar memperoleh uangnya kembali, sebelum uang diserahkan, pihak yang meminjam uang (debitur) agar memberikan jaminan terlebih dahulu, baik berupa rumah, tanah dan bangunan lainnya.

Sehingga dengan adanya jaminan tersebut akan memberikan rasa aman dan terjamin bagi kreditur bahwa uangnya pasti akan kembali tepat pada waktunya. Sedangkan bagi debitur terikat mengembalikan atau melunasi hutangnya sesuai dengan waktu yang telah diperjanjikan.

Sebenarnya semua harta seseorang baik yang sudah ada maupun yang akan ada diperoleh di kemudian hari menjadi jaminan untuk pembayaran hutang yang bersangkutan. Hal ini telah ditentukan dalam pasal 1131 dan pasal 1132 Kitab Undang-Undang Hukum Perdata menetapkan bahwa

Segala kebendaan si berutang (debitur) baik yang bergerak maupun yang tidak bergerak, baik yang sudah maupun yang baru akan ada di kemudian hari, menjadi tanggungan (jaminan) untuk segala perikatannya perseorangan.

Ini berarti bahwa semua. harta kekayaan. seseorang baik yang sudah. ada maupun. yang akan. ada dijadikan jairtirian untuk semua hutangnya. Kemudian yang dimaksud. dengan haring-barang yang Baru akan. ada kemudian hari adalah semua barang yang menjadi milik debitur setelah perjanjian diadakan.

Dengan demikian kalau seseorang mempunyai suatu hutang maka dapat jaminannya semua kekayaannya, kekayaan tersebut dapat diambil suatu jumlah tertentu untuk membayar hutangnya kepada krediturnya.

Kemudian pasal 1132 Kitab Undang-Undang Hukum. Pardata menetapkan pula bahwa:

Kebendaan tersebut menjadi jaminan bersama-sama bagi semua orang yang mengutangkan padanya, pendapatan penjualan benda-benda itu dibagibagikan menurut keseimbangan yaitu menurut besar kecilnya hutang masingmasing kecuali apabila di antara para berpiutang alasan-alasan sah untuk didahulukan.

Dari ketentuan pasal 1132 di atas ini menunjukkan bahwa status krediturnya semuanya adalah sama yaitu sebagai kreditur konkuren, yang maksudnya sama-sama berhak atau kreditur bersaing. Mereka semua kedudukannya sama dan tidak ada yang didahulukan pemenuhannya dari yang lain. Dengan demikian penjualan dari benda-benda jaminan tersebut hasil dibagi-bagikan diantara para kreditur secara seimbang dengan besar kecil.nya. piutang masing-masing.

Adapun sebagai lawan dari kreditur konkuren sebagaimana yang terdapat dalam pasal 1132 di atas adalah kreditur preferen. Para kreditur preferen ini mempunyai kedudukan yang istimewa. dari kreditur konkuren 
yakni mempunyai hak prevelegi atau preferent, yang dalam pemenuhan piutangnya dilebih dahulukan dari pada kreditur konkuren. Dengan demikian dapat terjadi apabila pendapatan penjualan benda-benda debitur itu hanya cukup membayar hutang-hutangnya kepada kreditur yang oleh. UndangUndang diberi. hak preferensi tersebut makes kreditur-kreditur lainnya sudah tidak menerima apa-apa lagi.

Pada pasal 24 a undang-undang pokok perbankan, dinyatakan "Bank Umum tidak memberikan kredit tanpa jaminan pada siapapun juga", disni dapat disimpulkan bahwa khususnya diadakan bagi pemberian kredit itu. Selanjutnya dijelaskan dalam penjelasan undang-undang pokok perbankan bahwa yang dimaksud dalam pasal 24 a ini adalah jaminan dalam arti luas jaminan yang bersifat materil antara lain bahwa bank dalam menilai permintaan kredit biasanya berpedoman pada faktor tertentu yang dikenal adanya beberapa formulasi. Formulasi yang digunakan itu antara lain lazimnya adalah faktor the 4'P' s of credit yaitu:

a. Puposes: artinya mengetahui data tentang tujuan atau keperluan penggunaan kreditur tersebut

b. Prosanality: artinya usaha peminjam seperti riwayat hidup, hobbi pergaulan dan pendapat masyarakat tentang diri si peminjam dan lainlainnya.

c. Prospect: artinya harapan masa depan dari bidang usaha atau kegiatan usaha si peminjam kredit

d. Payment: artinya mengetahui bagaimana pembayaran kembali pinjaman yang akan diberikan diperoleh dengan pertimbangan atau perhitungan tentang prospect kelancaran penjualan dan pendapatan usaha pemohon kredit.

Selain dari formulasi yang telah dijelaskan di atas diketahui ada formulasi lain yang dikenal the $5^{\prime} \mathrm{C}^{\prime} \mathrm{S}$ of Credit yaitu antara lain :

a. Capital: artinya ialah modal yang dipunyai oleh calon peminjam sebelumnya ia mendapatkan kredit, dimana akan mengurangi resiko kredit bagi bank

b. Capacity: ialah kemampuan peminjam dalam mengendalikan usahanya kesanggupan dalam menggunakan fasilitas kredit yang diberikan, dihubungkan dengan kemampuan membayar kembali semua pinjamannya

c. Collateral : artinya jaminan bagi pemberian kredit tersebut

d. Character: hampir sama dengan personality, yakni sifat pribadi yang meliputi tingkah laku sehari-hari si peminjam, keluarga, riwayat dari pinjamannya yang berhubungan dengan bidang usahanya

e. Condition: adalah kondisi atau keadaan perkembangan ekonomi saat ini.

Dalam rangka memajukan dan melindungi pengusaha ekonomi lemah dalam memajukan dan mengembangkan usahanya, pemerintah melalui pihak perbankan telah banyak memberikan keringanan dengan prosedur atau tata cara permohonan kredit menjadi lebih sederhana dan syarat-syarat jaminannya longgar, yaitu jika sertifikat sementara belum ada maka surat bukti pembayaran pajak bumi dan bangunan dapat dipakai sebagai bukti hak atas jaminan yang berupa tanah tanpa penelitian tahun dikeluarkan surat pajak itu. 
Dengan demikian kelihatan bank sangat berperan dalam memajukan perekonomian dengan kebijaksanaan di bidang perkreditan.

\section{Lembaga Jaminan \\ Pengertian lembaga jaminan}

Dalam kitab undang-undang Hukum Perdata Indonesia dikenal jenisjenis lembaga jaminan yang pada umumnya dapat digolongkan menurut kewenangan menguasainya adalah:

1. Jaminan umum dan jaminan perorangan

2. Jaminan kebendaan dan jaminan perorangannya

3. Jaminan atas benda bergerak atau benda tetap

4. Jaminan dengan menguasai benda dan tanpa menguasai bendanya.

Ad. 1. Jaminan umum dan jaminan khusus.

Jaminan umum dan jaminan khusus ini dilihat berdasarkan pada sifat jaminan tersebut. Jaminan umum di sini maksudnya adalah dalam pasal 1131 dan 1332 kitab undang-undang hukum perdata, hal mana jaminan diberikan bagi kepentingan semua kreditnya dan menyangkut semua harta kekayaan debitur.

Artinya benda itu tidak ditunjuk secara khusus secara seimbang dengan besar kecilnya piutang masing-masing. Para kreditur tersebut mempunyai kedudukan yang sama (congruent). Kreditur konkruent ini dikalahkan oleh kreditur preferent (Pemegang hipotik, gadai dan prevelagi yang lain), lebih diutamakan dari pada pemegang prevelagi yang lain.

Mengenai jaminan umum ini Sri Soedewi mengemukakan sebagai berikut:

Menurut prakteknya dalam perkreditan jaminan umum ini tidak memuaskan bagi krediturnya, dan kurang menimbulkan rasa aman serta kurang terjamin bagi kreditur yang diberikan.

Jadi kreditur memerlukan badan-badan tertentu yang ditunjuk secara khusus yang diadakan antara kreditur yang dapat berupa jaminan yang bersifat kebendaan maupun bersifat perorangan jaminan-jaminan khusus yang dalam praktek sudah dilembagakan adalah hipotik, creditvarband, gadai, fiducia, borgtoch, perjanjian garansi, juga perjanjian tanggung menanggung.

Ad. 2. Jaminan kebendaan dan jaminan perorangan.

Hukum perdata mengenal jenis jaminan yang bersifat kebendaan dan jaminan bersifat perorangan. Jaminan yang bersifat kebendaan adalah adanya bendabenda tertentu yang dipakai sebagai jaminannya sedangkan yang bersifat perorangan adalah orang tertentu yang sanggup membayar prestasi manakala debitur melakukan wanprestasi.

Dalam praktek perbankan jaminan yang dilembagakan sebagai kebendaan adalah berupa hipotik creditverbind, gadai dan fiducia. Sedangkan jaminan yang bersifat perorangan adalah berwujud perjanjian penanggungan, perjanjian garansi dan perutangan tanggung menanggung. Pada jaminan perorangan ini debitur merasa terjamin karena mempunyai lebih dari seorang debitur yang dapat untuk memenuhi perutangan.

Pada jaminan kebendaan kreditur merasa terjamin karena mempunyai hak preferensi dalam pemenuhan piutangnya atas eksekusi terhadap benda-benda debitur.

Ad. 3. Jaminan atas benda dan benda tetap 
Perbedaan antara kedua jaminan ini dalam hukum perdata amat penting dalam hal-hal tertentu yaitu mengenai:

- Bezit

- Cara pembebanannya atau pemasangannya

- Cara penyerahan

- Dalam hal daluarsa

Dalam hukum perdata mengenai lembaga jaminan penting sekali artinya dari pembagian benda bergerak dan benda tetap tak bergerak. Atas dasar pembedaan benda tersebut menentukan jenis lembaga yang dapat dipasangkan untuk kredit yang akan diberikan.

Menurut Prof. Dr. Sri Soedewi bahwa perbedaan benda bergerak dan benda tidak bergerak dalam lembaga jaminan tetap penting, sebagai mana diakui dalam yurisprudensi yang tetap mengadakan perbendaan antara benda bergerak dan benda tidak bergerak.

Selanjutnya beliau berpendapat bahwa sesuai dengan keadaan praktek perbankan Indonesia, untuk memenuhi perkembangan kebutuhan masyarakat, fiducia dapat juga dipakai atas benda-benda tak bergerak asal saja didaftarkan dan memenuhi syarat-syarat tertentu.

Karenanya perbedaan benda bergerak dan tidak bergerak dalam lembaga jaminan adalah tetap penting. Hal mana sesuai dengan keputusan MA tanggal 1 September 1971 dalam perkara Lo Ding Siang melawan Bank Indonesia, yang menetapkan bahwa banyak benda-benda bergerak yang dapat difiduciakan, sedangkan benda-benda tidak bergerak dapat dipakai sebagai jaminan fudicia.

Ad. 4 Jaminan dengan menguasai bendanya dan tanpa menguasai bendanya.

Adapun jaminan yang menguasai bendanya dan tanpa menguasai bendanya dibedakan demi untuk pengamanan pembayaran kembali kredit yang diberikan.

Jaminan yang diberikan dengan menguasai benda bagi kreditur lebih aman terutama jika ditujukan pada benda bergerak yang gampang dipindahkan dan berubah nilainya. Jaminan dengan menguasai bendanya misalnya pada gadai, hak retensi.

Sedangkan jaminan yang diberikan tanpa menguasai bendanya dijumpai pada hipotik, kreditverband dan fudicia.

Jaminan yang diberikan tanpa menguasai bendanya dalam praktek banyak dipakai, dan bank dalam prakteknya menggunakan jaminan tanpa menguasai bendanya, maka hal ini pengawasan yang serius pemberian kredit jaminan perlu dilakukan.

\section{Peranan Bank dalam Memberikan Fasilitas Pinjaman Kredit}

Dalam kehidupan perekonomian, Bank memegang peranan yang sangat penting selaku lembaga keuangan dengan membantu pemerintah dalam rangka mencapai kemakmuran. Sebagai lembaga pemerintah kredit, maka pengertian tentang kredit tidak dapat dipisah-pisahkan.

Peranan Bank dalam memberi fasilitas kredit dengan menggunakan rumah dan bangunan sebagai jaminan, terbagi atas dua bagian yaitu:

1. Peranan bank dalam menyediakan uang atau dana 
Didalam undang-undang pokok perbankan No. 10 Tahun 1998, telah secara tegas ditentukan pemberi kredit adalah Bank. Bank adalah lembaga keuangan yang usaha pokoknya memberikan kredit dan jasa-jasa dalam lalulintas pembayaran dan peredaran uang. Dengan peranannya tersebut maka bank adalah suatu lembaga keuangan yang mempunyai tugas:

a. Pengembangan unit-unit usaha yang telah dilaksanakan:

Misal:

- Dalam biaya perkebunan

- Dalam bidang jasa

b. Dengan dana yang disalurkan bank tersebut maka dapat menambah volume usaha dari perusahaan atau toko tersebut

c. Dari hasil kredit yang diberikan oleh Bank tersebut maka pengusaha dapat meningkatkan tempat usahanya atau sarana penunjang usaha

2. Peranan Bank dalam Pembinaan Organisasi Usaha

Selain menyediakan uang atau dana, maka bank juga mempunyai peranan guna meningkatkan organisasi usaha atau perusahaan, dengan melakukan pembinaan-pembinaan kepada organisasi usaha dengan jalan:

a. Dalam melaksanakan peranannya pembinaan oleh Bank sendiri dilakukan usaha-usaha:

1. Bank memberikan pengarahan terhadap administrasi dari perusahaan tersebut

2. Memberikan petunjuk dalam hal keuangan dan pembukuan perusahaan tersebut

3. Bank dapat memberikan petunjuk, usaha-usaha yang ditunjuk oleh Bank

Dimana di dalam praktek di ketahui bahwa peranan bank hanya berfungsi untuk menyediakan uang saja. Sedangkan dalam teorinya, selain menyediakan dana maka Bank berkewajiban melakukan pembinaan dan pengawasan terhadap usaha dan badan usaha tersebut.

\section{Tata Cara Pemberian Kredit}

Sebagai lembaga kredit, bank harus dapat menentukan policy atau kebijaksanaan umum yang harus ditempuhnya. Dalam memberikan kredit maka setiap bank mempunyai tata cara tersendiri yang disesuaikan dengan peraturan perkreditan.

Adapun ketentuan yang mengatur tentang tata cara pelaksanaan pemberian kredit antara lain:

1. Undang-undang pokok perbankan (UU No. 10/ 1998) tentang perkreditan

2. Surat edaran Bank Indonesia No. 22/ 4/ UKK Tanggal 29 Januari 1990, perihal Kredit Usaha Kecil

3. Surat edaran Bank Indoensia No. 22 / 6/ UKU tanggal 29 Januari 1990, perihal kredit investasi

Berdasarkan surat edaran bank Indonesia dan undang-undang perbankan itulah, setiap bank mempunyai kebijaksanaan tersendiri dalam tata cara pemberian kredit.

Dalam pencarian atau menyetujui permohonan kredit, cepat atau lambatnya sangat tergantung kepada permohonan. Bila syarat-syarat dalam 
permohonan itu lengkap dan permohonan sanggup mengikuti ketentuanketentuan bank, yang pada prinsipnya memajukan dan membantu semua jenis usaha dan perusahaan, maka keputusannya akan cepat dilaksanakan.

Selain itu pemohon kredit harus melengkapi syarat-syarat, yaitu: Jenis dokumen/ keterangan yang harus dilampirkan pada permohonan kredit

Semua syarat-syarat untuk memperoleh kredit tersebut berlaku untuk semua jenis kredit, seperti kredit usaha kecil dan kredit investasiAntara teori ketentuan dengan kenyataan dalam praktek mengenai tata cara pemberian kredit dengan menggunakan jaminan rumah dan bangunan sebagai jaminan, merupakan suatu hal yang saling mendukung. Dengan adanya teori dan peraturan perundangan maka hal tata cara pemberian kredit pihak bank harus berpedoman kepada ketentuan dari perundangan-undangan tersebut.

Walaupun diketahui bahwa pemerintah melalui Bank Indonesia, memberikan kebebasan kepada setiap bank untuk membuat peraturan tersendiri dengan jaminan rumah dan bangunan. Tetapi dalam prakteknya bank-bank tidak boleh semuanya membuat ketentuan sendiri, dan bank dalam membuat peraturan harus berpedoman kepada peraturan yang ada seperti undang-undang pokok perbankan dan surat edaran bank Indonesia.

\section{Hak dan Kewajiban Para Pihak}

Dalam perjanjian pinjam uang pada bank dengan menggunakan rumah dan bangunan sebagai jaminan, maka para pihak yang turut serta yaitu: permohonan atau peminjam uang maupun bank mempunyai hak-hak kewajibannya masing-masing.

a. Hak dan kewajiban pemohon kredit

a. Hak dan kewajiban pemohon kredit

Permohonan kredit setelah memenuhi syarat-syarat yang telah ditetapkan dalam permohonan kredit, mereka berhak menerima sejumlah uang pinjamannya kemudian mereka berhak menggunakan uang itu.

Selain itu pemohon juga mempunyai hak-hak lain yaitu:

1) Nasabah berhak menerima sisa dana yang ada di Bank sesuai dengan sisa saldonya yang masih ada

2) Menerima atau mengetahui tentang keadaan atau posisi saldonya di bank

3) Menerima atau mengetahui laporan salinan R/L-nya

b. Kewajiban pemohon kredit

Dalam pasal 1755 Kitab Undang-undang Hukum Perdata, menentukan bahwa jika barang yang dipinjam itu musnah dengan cara bagaimanapun maka kemusnahan itu adalah tanggungannya. Demikian juga dengan peminjam kredit itu. Berhubungan dengan itu kitab undang-undang hukum perdata pasal 1763 menentukan bahwa:

"Siapa yang menerima pinjaman sesuatu diwajibkan mengembalikannya dalam jumlah dan keadaan yang sama dan pada waktu yang telah ditentukan".

Dalam setiap kegiatan pinjam meminjam selalu terkandung adanya pemungutan bunga. Bunga pada dasarnya mempunyai dua 
pengertian sesuai dengan peminjamannya yaitu:

a. Bagi bank, bunga adalah suatu pendataan atau keuntungan uang oleh pengusaha atau nasabah

b. Bagi pengusaha, bunga dianggap sebagai ongkos produksi atau biaya modal

Setiap menerima pinjaman dari bank, diwajibkan untuk membayar sejumlah biaya yang diperlukan guna persiapan perjanjian kredit.

Biaya ini antara lain terdiri dari:

a. Biaya materai

b. Biaya provisi kredit

c. Biaya notaris

d. Biaya komitmen

e. Biaya asuransi barang jaminan atau asuransi kebakaran

Permohonan kredit mempunyai kewajiban-kewajiban didalam kitab undang-undang hukum perdata maupun dalam undang-undang pokok perbankan. dengan jaminan rumah dan bangunan pada Bank banyak pengaturan lebih lanjut tentang kewajiban-kewajiban permohonan.

Akan tetapi kewajiban yang diatur dalam kitab undang-undang hukum perdata, maupun undang-undang pokok perbankan serta ketentuan yang dikeluarkan oleh Bank Sirkulasi.

Hak dan Kewajiban Pemberi Kredit (Bank)

c. Hak Bank

Pasal 1763 s/d pasal 1769, buku III, bab ke 13 kitab undang-undang hukum perdata, mengatur tentang hak-hak bank. Pasal 1763 KUH Perdata, menyatakan bahwa: "Siapa yang menerima pinjaman sesuatu diwajibkan mengembalikannya dalam jumlah dan keadaan yang sama, dari waktu yang ditentukan".

Sedangkan pasal 1765, menentukan: "adalah diperbolehkan memperjanjikan bunga atas pinjaman uang itu menggunakan jaminan dan bangunan maupun jaminan lain. Bank berhak menerima pembayaran kembali dengan bunganya.

Selain dari pada hak-hak bank yang diatur dalam kitab undang-undang hukum perdata, berdasarkan hasil penelitian penulis, hak-hak bank yaitu:

1) Hak provisi, hak untuk mendapatkan hasil dari pemeriksaan pendahuluan atas permohonan kredit nasabah (1\% untuk kredit investasi dan 0,5 untuk kredit modal kerja)

2) Komitmen yaitu biaya yang dilaksanakan kepada nasabah karena bank menyediakan dana sebesar $0,75 \%$ (dari sisa dana yang belum ditarik untuk kredit investasi).

3) Kuasa untuk menjual dan menerima barang-barang jaminan

4) Kuasa untuk mengosongkan rumah/ jaminan

5) Hak untuk menentukan suku bunga

6) Hak untuk mengambil alih usaha pemohon

7) Hak untuk memungut biaya tambahan

8) Bank berhak untuk menerima realisasi usaha setiap bulan 
d. Kewajiban bank

Di dalam kitab undang-undang hukum perdata juga diatur tentang kewajiban orang yang meminjamkan yaitu terdapat dalam buku III, bab ke 13, bagian ke 2 yaitu pasal 1759, 1760 dan 1762. Selain dari ketentuan yang mengatur tentang kewajiban bank yang terdapat dalam kitab undang-undang hukum perdata, juga diketahui beberapa kewajiban lainnya, dalam memberikan pinjaman dengan jaminan rumah dan bangunan, berdasarkan hasil penelitian yaitu :

1) Bank memiliki kewajiban pokok menyediakan dana kredit sesuai dengan tujuan kredit dalam jangka waktu perjanjian.

2) Bank wajib menyampaikan keadaan saldo pinjaman setiap bulan

3) Bank berkewajiban melakukan pemeriksaan lapangan atas permohonan kredit

4) Bank wajib untuk mengadakan pembinaan dan pengawasan yaitu berupa:

- Perhatian untuk membayar bunga

- Kunjungan ke tempat usaha nasabah

- Mengetahui usaha aktif atau tidak

5) Mengeluarkan blanko administrasi atau alat untuk memperlancar pengambilan dan penyetoran uang, seperti cek, giro, buku setoran dan mengeluarkan sertifikat jaminan.

\section{Hambatan-hambatan dalam Pemberian Kredit} kredit.

hambatan-hambatan yang terdapat dalam pelaksanaan perjanjian

a. Hambatan dilihat dari pihak pemohon

Hambatan diri pemohon timbul karena pemohon tidak memenuhi syaratsyarat yang dijadikan jaminan bukan milik sendiri. Sehingga pihak bank pun ragu dalam memberikan putusan untuk pemberian kredit tidak mau mengambil resiko seandainya pada suatu waktu pengusaha tersebut rugi atau wanprestasi. Karena dengan adanya peristiwa tersebut akan mengganggu mobilitas juga stabilitas bank.

- Misal bangunan tidak ber IMB (Izin Mendirikan Bangunan)

- Tanahnya belum bersertifikat

b. Hambatan dilihat dari pihak bank, sebagai berikut:

a. Dana yang disalurkan sangat terbatas

Kredit yang didapat pengusaha dari bank sebagai modal tambahan, sangat dibutuhkan sekali, sedangkan jumlah dana yang disalurkan oleh bank sangat terbatas. Hal ini terjadi karena banyaknya permohonan kredit yang diajukan oleh pengusaha. Sedangkan apabila banyak permohonan kredit pada tahun anggaran itu, maka akibatnya bank sirkulasi tidak dapat memenuhi permohonan kredit pengusaha Pengusaha ekonomi lemah yang ada di perkotaan sangat membutuhkan sekali modal yang berasal dari kredit bank. Permohonan kredit jumlahnya semakin bertambah akan tetapi jumlah dananya masih terbatas.

b. Terbatasnya jumlah AO (Account Officer) 
Untuk dapat memutuskan kredit, maka pihak bank harus mengadakan peninjauan ke lokasi usaha atau lokasi barang jaminan terletak. Untuk mengadakan pemeriksaan sangat dibutuhkan tenaga $\mathrm{AO}$, dan jumlahnya masih kurang,

Dokumen-dokumen yang harus disiapkan untuk melengkapi permohonan kredit, juga dirasakan sebagai faktor penghambat. Hal itu disebabkan, karena pada umumnya dokumen-dokumen itu barulah memperhatikan jika kredit akan diajukan, dokumen-dokumen itu misalnya : seperti sertifikat hak-hak atas tanah, pembayaran pajak dan lain-lain.

Prosedur memperoleh kredit sulit, hal ini adalah akibat sikap pengusaha ekonomi lemah belum sesuai dengan hal-hal dituntut oleh administrasi dan organisasi yang baik dalam lalu lintas sesuatu badan usaha. Faktor pemghambat ini dapat diatasi dengan cara, semua dokumen secara wajar harus dimiliki badan-badan usaha atau perseorangan yang berusaha itu harus telah disiapkan terlebih dahulu. Kelemahan ini dapat juga diatasi dengan pembinaan yang terarah oleh pihak bank, terhadap pengusaha ekonomi lemah

\section{KESIMPULAN}

a. Dalam kehidupan perekonomian, bank memegang peranan yang sangat penting selaku lembaga keuangan dengan membantu pemerintah dalam rangka mencapai masyarakat adil dan makmur seperti yang dicita-citakan. Dalam melaksanakan peranannya tersebut, bank bergerak dalam bidang memberikan fasilitas kredit/ pinjam uang dan sekaligus berperan melakukan pembinaan terhadap organisasi usaha. Bank memberikan fasilitas pinjaman uang terutama kepada pengusaha kecil dan golongan ekonomi lemah, serta pedagang yang kekurangan modal untuk meningkatkan dan memperluas usahanya dengan syarat-syarat yang ringan dan prosedur relatif mudah.

b. Sebagai lembaga kredit, bank harus dapat menentukan policy atau kebijaksanaan umum yang harus ditempuhnya. Dalam memberikan kredit maka setiap bank mempunyai tata cara tersendiri yang disesuaikan dengan peraturan perkreditan.

\section{DAFTAR KEPUSTAKAAN}

Alanshari, F., \& Marlius, D. (2018). Prosedur Pemberian Kredit KPR Pada PT. Bank Tabungan Negara (Persero) TBK Cabang Pembantu Bukittinggi. https://doi.org/10.31227/osf.io/rsfhc

Burma Burhan, Hukum Perjanjian. Diktat Kuliah. Fakultas Hukum UNAND Padang, 1990, hal 17.

Darmawanto, \& Fernos, J. (2019). Prosedur Pemberian Kredit Pada Bank Nagari Cabang Sijunjung. https://doi.org/10.31227/osf.io/psqfy

Hadiwidjaja, H. Akk dan Drs. Ec. R. A. Rivai Wirasasmita M. Analisis 
Kredit, Penerbit Pionir Jaya, Bandung, 1990.

Subekti R., Hukum Perjanjian, Cetakan Ke-X, Penerbit PT. Internusa, Jakarta, 1985.

Ikbal, M., \& Marlius, D. (2017). Pengaruh Jumlah Taksiran Dan Uang Pinjaman Terhadap Laba Bersih Pada PT. Pegadaian (UPC) Gurun Laweh. https://doi.org/10.31227/osf.io/uch4a

Setiawan R., Pokok-pokok Hukum Perikatan, Penerbit Bina Cipta, Bandung, 1970.

Sri Soedewi Masjchun Sofwan, Hukum Perdata, Hukum Perutangan Bagian B, Penerbit Seksi Hukum Perdata Fakultas Hukum UGM, Yogyakarta. 1980

Subekti, R., Jaminan-jaminan Untuk Pemberian Kredit Menurut Hukum Indonesia, Alumni Bandung, 1978.

Sri Soedewi Masjhun Sofwan, Hukum Jaminan di Indonesia Pokok-pokok Hukum Jaminan dan Jaminan Perorangan, Liberty, Yogyakarta, 1980

Widayati, R. (2019). Pelaksanaan Prinsip Kehati-Hatian Dalam Pemberian Kredit Konsumtif Pada Bank Nagari Cabang Siteba. https://doi.org/10.17605/OSF.IO/FZVXR

Widayati, R. (2019). Aktivitas Pemberian Kredit Komersil Pada Bank Nagari Cabang Sijunjung. https://doi.org/10.17605/OSF.IO/QTVZ9

Widayati, R. (2019). Pelaksanaan Kredit Pada Bank Perkreditan Rakyat LPN Pasar Baru Durian Sawahlunto. https://doi.org/10.17605/OSF.IO/5HPAB

Widayati, R. (2019). Aktivitas Pemberian Kredit Usaha Pada PT. Bank Perkreditan Rakyat Batang Kapas. https://doi.org/10.17605/OSF.IO/EDPN4

Yasman, R., \& Afriyeni, A. (2019). Prosedur Pemberian Kredit Pada PT. Bank Pekreditan Rakyat (BPR) Jorong Kampung Tangah (JKT) Pariaman Cabang Padang. https://doi.org/10.31219/osf.io/c5ufr 